\title{
Original
}

\section{Pine Cone Antitumor Substances Stimulate Cytotoxic Factor Production in Young Mice, but not in Aged or Tumor-Bearing Mice}

\author{
Ayumi HanaOKa ${ }^{1)}$, Hiroshi SAKagami ${ }^{2)}$ and Kunio KonNo ${ }^{2)}$
}

\begin{abstract}
Mice produce a cytotoxic factor (CF) against mouse fibroblast L-929 cells. Production of this factor was investigated in young, aged, and tumorbearing mice. Intravenous administration of pine cone antitumor substances (Fr. VI or VII), followed by OK-432, caused higher amounts of CF to be produced in ICR mouse serum fractions. Significant loss of CF activity by heat or trypsin treatment suggests that the active principle(s) of the induced factor(s) might be proteineous substance(s). Tumor-bearing and aged mice produced much lower amounts of $\mathrm{CF}$ activity than normal and young mice, when stimulated with pine cone extracts and OK-432.
\end{abstract}

Key words: pine cone extracts, cytotoxic factor, endogenous production, aging, tumor development

\section{Introduction}

There is a folk legend that oral administration of hot water extract of pine cone of Pinus parviflora Sieb. et Zucc. is effective against gastric cancer. Partial purification of 10 different fractions of pine cone extracts revealed that the $10 \mathrm{kD}$ Fr. VI and the $70-200 \mathrm{kD}$ Fr. VII of $\mathrm{NaOH}$ extract had the most potent antitumor activity. ${ }^{1)}$ We previously reported that these fractions stimulated the production of differentiation-inducing factor(s) by macrophages, ${ }^{1)}$ granulocytic cell iodination ${ }^{2)}$ and splenocyte proliferation.") These fractions also induced antimicrobial activity ${ }^{4)}$ and antiparasite activityi) in mice, and inhibited the proliferation of herpes simplex virus in various cultured cells. ${ }^{6, \tau)}$ We have tentatively concluded that the active principle of Fr. VI or Fr. VII might be complex(s) of lignin-like polyphenolic skeleton with molecular matrices of hydrophilic components such as neutral sugars or polysaccharides. $^{8)}$

It is believed that endogenous production of tumor necrosis factor (TNF) or cytotoxic factor $(\mathrm{CF})$ by various biological response modifiers is a promising approach to cancer therapy. ${ }^{9)}$ We report here, investigation of whether intravenous administration of Fr. VI or VII, followed by elicitation with OK-432, can endogenously induce such soluble factor(s). We also investigated possible fluctuation of $\mathrm{CF}$ production by mice after tumor transplant and during aging.

\section{Materials and Methods}

Pine cones of Pinus parviflora Sieb. et Zucc. were supplied by Mr. S. Matsuda, and Mr. S. Sato. OK-432, a preparation of Streptococcus pyogenes, ${ }^{10)}$ was supplied by Chugai Seiyaku

\footnotetext{
1) Section of Pharmacy, Showa University Hospital, 1-5-8 Hatanodai, Shinagawa-ku, Tokyo 142, Japan.

$\Rightarrow$ First Department of Biochemistry, Showa University School of Medicine.
} 
Co., Tokyo.

Mice. Female ICR mice (5 weeks old, 23-25 g) were obtained from Sankyo Labo. Service Co.

Tumors. Sarcoma-180 was maintained serially in ascites by weekly in vivo transfer in ICR mice.

Cell culture. Mouse fibroblast L-929 cells and human myeloblastic leukemic ML-1 cells were maintained at $37^{\circ} \mathrm{C}$ in RPMI 1640 medium (GIBCO) supplemented with $10 \%$ heatinactivated fetal bovine serum (FBS) in a $\mathrm{CO}_{2}$-incubator, as described previously. ${ }^{11)}$

Isolation of antitumor substances. Antitumor substances (Frs. VI and VII) were prepared from $\mathrm{NaOH}$ extract of pine cone of Pinus parviflora Sieb. et Zucc. as described previously. ${ }^{1)}$ In brief, pine cones were extensively washed with methanol, $85 \%$ ethanol and boiling water, and then extracted twice with $1 \% \mathrm{NaOH}$ for $4 \mathrm{hr}$ at room temperature. After centrifuging for $20 \mathrm{~min}$ at $10,000 \times \mathrm{g}$, the $\mathrm{pH}$ of the clarified supernatant was adjusted to 5.0 with acetic acid. The precipitate (Fr. VI) was collected by centrifugation, dissolved in a small volume of $\mathrm{NaOH}$ to remove insoluble materials and then neutralized. The remaining supernatant (Fr. VII) was precipitated with one volume of ethanol. All of these fractions were extensively dialyzed against distilled water and lyophilized.

Preparation of cytotoxic serum. Mice were intravenously administered $0.2 \mathrm{ml}$ of the indicated doses of test samples dissolved in $0.9 \% \mathrm{NaCl}$, followed $3 \mathrm{hr}$ later by $8 \mathrm{mg} / \mathrm{kg}$ of OK-432. After $2 \mathrm{hr}$, the serum was collected from the exsanguinated mice and stored at $-20^{\circ} \mathrm{C}$ until use.

Cytotoxicity assay. CF activity of the serum samples was tested for cytotoxicity against L-929 cells. $^{12)}$ In brief, trypsinized L-929 cells were inoculated at a density of $3 \times 10^{4} / 0.1$ $\mathrm{ml}$ of culture medium in an F96 MicroWell (Nunc, InterMed) and incubated for $8 \mathrm{hr}$ at $37^{\circ} \mathrm{C}$. After adding $0.1 \mathrm{ml}$ of $2 \mu \mathrm{g} / \mathrm{ml}$ actinomycin $\mathrm{D}$ and $50 \mu \mathrm{l}$ of serially diluted serum preparations, the cells were further incubated for $18 \mathrm{hr}$. The viable L-929 cells were stained with $0.2 \%$ crystal violet in $2 \%$ ethanol, and lysed with $1 \%$ SDS. Absorbance of the cell lysates was measured at $590 \mathrm{~nm}$ with ImmunoReader NJ-2000 (InterMed). One unit of CF activity was defined as the amount necessary to reduce absorbance of the control cells $50 \%$. Heat stability of $C F$. The serum sample was heated at $70^{\circ} \mathrm{C}$ for $30 \mathrm{~min}$, and then immediately cooled in ice water prior to cytotoxicity assay.

Trypsin digestion. The serum sample was incubated for $30 \mathrm{~min}$ at $37^{\circ} \mathrm{C}$ with $3 \mathrm{mg} / \mathrm{ml}$ trypsin (DIFCO), and $5.5 \mathrm{mg}$ trypsin inhibitor (Sigma) was added to stop the digestion.

\section{Results}

Stimulation of CF production by Frs. VI and VII.

The amount of cytotoxic factor (CF) produced in the serum of the ICR mice was measured by L-929 cell cytotoxicity assay in the presence of $1 \mu \mathrm{g} / \mathrm{ml}$ actinomycin D (Table 1). Single or double intravenous administration of Fr. VI $(10 \mathrm{mg} / \mathrm{kg})$ induced relatively weak CF activity. However treatment with OK-432 $(8 \mathrm{mg} / \mathrm{kg})$ induced higher amounts of CF. Administration of Fr. VI $(10 \mathrm{mg} / \mathrm{kg})$ or Fr. VII $(20 \mathrm{mg} / \mathrm{kg}), 3 \mathrm{hr}$ before OK- 432 treatment, further increased $\mathrm{CF}$ production to a level almost equal to that attained by double OK-432 injection. The stimulation effect of Fr. VI was detectable at $1-20 \mathrm{mg} / \mathrm{kg}$, but decreased at higher concentrations (Fig. 1). The 50\% lethal doses of intravenously administered Fr. VI, Fr. VII and OK-432 were about 60,80 and $16 \mathrm{mg} / \mathrm{kg}$, respectively. We found that near lethal doses 


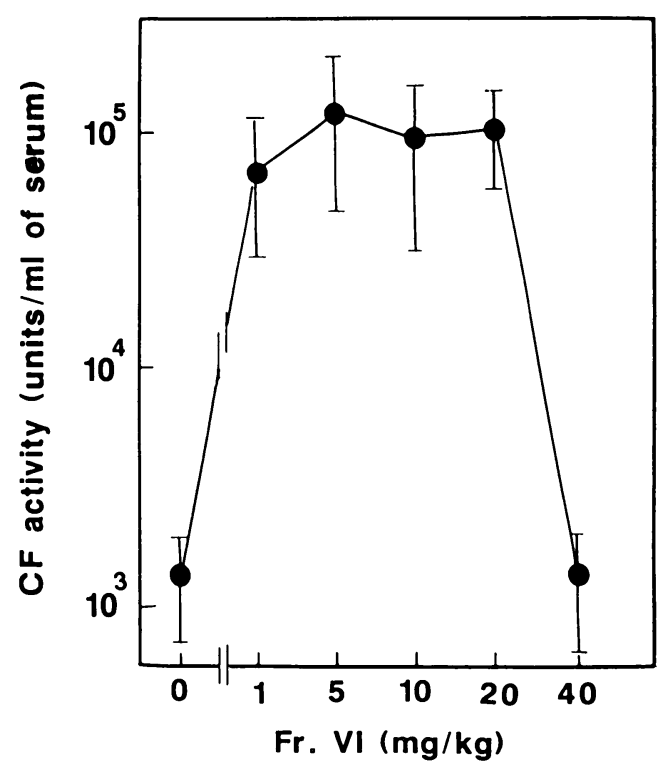

Fig. 1. Dose-dependent effect of Fr. VI on OK-432-elicited cytotoxic factor production. Mice (6 weeks old) were administered i.v. either saline (control) or indicated doses of Fr. VI, followed $3 \mathrm{hr}$ later by OK-432 $(8 \mathrm{mg} / \mathrm{kg})$. Two hr thereafter, CF activity in the serum was determined.

Each value is mean \pm S.E. of 3 mice.

Table 1. Induction of endogenous CF production by sequential administration of Fr. VI or Fr. VII and OK-432.

\begin{tabular}{|c|c|c|}
\hline \multicolumn{2}{|c|}{ Treatment } & \multirow{2}{*}{$\begin{array}{c}\mathrm{CF} \text { activity } \\
\text { (units/ml of serum) }\end{array}$} \\
\hline $1 \mathrm{st}$ & 2nd & \\
\hline Saline & Saline & $<8 \pm 2$ \\
\hline Saline & Fr. VI & $20 \pm 11$ \\
\hline Saline & Fr. VII & $7 \pm 3$ \\
\hline Fr. VI & Fr. VI & $23 \pm 1$ \\
\hline Saline & OK-432 & $488 \pm 232$ \\
\hline Fr. VI & OK-432 & $45762 \pm 23642$ \\
\hline Fr. VII & OK-432 & $22083 \pm 6305$ \\
\hline $\mathrm{OK}-432$ & OK-432 & $30476 \pm 12597$ \\
\hline
\end{tabular}

Mice (6 weeks old) ( 3 mice/group) were intravenously administered saline, $10 \mathrm{mg} / \mathrm{kg}$ Fr. VI, $20 \mathrm{mg} / \mathrm{kg}$ Fr. VII or $8 \mathrm{mg} / \mathrm{kg} \mathrm{OK}-432$, and $3 \mathrm{hr}$ later injected with the same concentrations of the indicated samples. Two hr later, the serum was collected and CF activity in the serum fraction was determined.

Each value is mean \pm S.E. of 3 mice.

$(2-8 \mathrm{mg} / \mathrm{kg}$ ) of $\mathrm{OK}-432$ were required to elicit sufficient $\mathrm{CF}$ production (data not shown).

Table 2 shows that most of the CF activity induced in the mouse serum after treatment with Fr. VI and OK-432 was destroyed by heat treatment $\left(70^{\circ} \mathrm{C}, 30 \mathrm{~min}\right)$ or by trypsin digestion. This suggests that the active principle(s) in the stimulated serum might be proteineous substance(s). 
Table 2. Stability of serum CF activity induced by Fr. VI and OK-432.

\begin{tabular}{|c|c|c|c|}
\hline Pretreatment & & $\begin{array}{c}\mathrm{CF} \text { activity } \\
\text { (units/ml of serum) }\end{array}$ & (\% of control) \\
\hline \multicolumn{4}{|l|}{ Exp. I } \\
\hline $0^{\circ} \mathrm{C}$ & $30 \mathrm{~min}$ & 9766 & 100 \\
\hline $37^{\circ} \mathrm{C}$ & $30 \mathrm{~min}$ & 7813 & 80 \\
\hline $70^{\circ} \mathrm{C}$ & $30 \mathrm{~min}$ & 3 & 0.03 \\
\hline $100^{\circ} \mathrm{C}$ & $30 \mathrm{~min}$ & 20 & 0.2 \\
\hline \multicolumn{4}{|l|}{ Exp. II } \\
\hline None & & 6104 & 100 \\
\hline Trypsin & $(3 \mathrm{mg} / \mathrm{ml}) 37^{\circ} \mathrm{C} 30 \mathrm{~min}$ & 40 & 0.7 \\
\hline
\end{tabular}

Three mice ( 7 weeks old) were intravenously administered $10 \mathrm{mg} / \mathrm{kg} \mathrm{Fr}$. VI and after $3 \mathrm{hr}$ $8 \mathrm{mg} / \mathrm{kg} \mathrm{OK}-432$. Two $\mathrm{hr}$ thereafter, the sera of the exsanguinated mice were obtained. Aliquots of the pooled sera were heated (Exp. I) or digested with trypsin (Exp. II) under the indicated conditions, and the remaining CF activity was determined.

Table 3. Effect of tumor implantation on endogenous CF production.

\begin{tabular}{|c|c|c|c|c|}
\hline & \multicolumn{2}{|c|}{ Treatment } & \multirow{2}{*}{$\begin{array}{c}\mathrm{CF} \text { activity } \\
\text { (units/ml of serum) }\end{array}$} & \multirow{2}{*}{$\begin{array}{c}\text { Stimulation index } \\
(\mathrm{n}-\text { fold })\end{array}$} \\
\hline & $1 \mathrm{st}$ & 2nd & & \\
\hline \multicolumn{5}{|c|}{ Exp. I (Ascites tumor) } \\
\hline \multirow[t]{3}{*}{ Day 0} & Saline & OK-432 & $204 \pm 111$ & (1) \\
\hline & Fr. VI & OK-432 & $1009 \pm 411$ & (4.9) \\
\hline & Fr. VII & OK-432 & $4462 \pm 2663$ & $(21.9)$ \\
\hline \multirow[t]{3}{*}{ Day 8} & Saline & OK-432 & $305 \pm 126$ & (1) \\
\hline & Fr. VI & OK-432 & $2794 \pm 2090$ & $(9.2)$ \\
\hline & Fr. VII & OK-432 & $3888 \pm 2941$ & (12.7) \\
\hline \multirow[t]{3}{*}{ Day 13} & Saline & OK-432 & $24 \pm 0$ & (1) \\
\hline & Fr. VIa & OK-432 & $27 \pm 20$ & (1.1) \\
\hline & Fr. VII & OK -432 & $22 \pm 8$ & $(0.9)$ \\
\hline \multicolumn{5}{|c|}{ Exp. II (Solid tumor) } \\
\hline \multirow[t]{2}{*}{ Day 0} & Saline & OK-432 & $338 \pm 147$ & (1) \\
\hline & Fr. VI & OK-432 & $2697 \pm 854$ & $(8.0)$ \\
\hline \multirow[t]{2}{*}{ Day 13} & Saline & OK-432 & $640 \pm 465$ & (1) \\
\hline & Fr. VI & OK-432 & $625 \pm 248$ & $(1.0)$ \\
\hline
\end{tabular}

Mice ( 8 weeks old) were inoculated intraperitoneally (Exp. I) or subcutaneously (Exp. II) with $10^{6}$ sarcoma- 180 cells. At indicated days after inoculation, the mice were intravenously administered saline (control), $10 \mathrm{mg} / \mathrm{kg} \mathrm{Fr}$. VI, or $20 \mathrm{mg} / \mathrm{kg} \mathrm{Fr}$. VII, and after $3 \mathrm{hr}$ $8 \mathrm{mg} / \mathrm{kg}$ OK-432. Two $\mathrm{hr}$ thereafter, sera were obtained, and CF activity determined. Each value is mean \pm S.E. of 3 mice.

"Dus to the cytotoxicity of Fr. VI, the amount of Fr. VI administered was reduced from $10 \mathrm{mg} / \mathrm{kg}$ to $5 \mathrm{mg} / \mathrm{kg}$.

1 Stimulation index represents ratio of $\mathrm{CF}$ activity in Fr. VI (or Fr. VII)-stimulated serum vs CF activity in control serum. 
Table 4. Effect of aging on endogenous CF production.

\begin{tabular}{|c|c|c|c|c|c|}
\hline \multirow{2}{*}{$\begin{array}{c}\text { Age } \\
\text { (weeks) }\end{array}$} & \multirow{2}{*}{$\begin{array}{l}\text { Body } \\
\text { weight } \\
\text { (g) }\end{array}$} & \multicolumn{2}{|c|}{ Treatment } & \multirow{2}{*}{$\begin{array}{l}\text { CF production } \\
\text { (units/ml) }\end{array}$} & \multirow{2}{*}{$\begin{array}{l}\text { Stimulation index } \\
(n-f o l d)\end{array}$} \\
\hline & & 1st & 2nd & & \\
\hline 7 & 27 & Saline & OK-432 & $567 \pm 280$ & (1) \\
\hline 7 & 27 & Fr. VI & OK-432 & $6381 \pm 1517$ & (11.3) \\
\hline 7 & 27 & Fr. VII & OK-432 & $10148 \pm 1918$ & (17.9) \\
\hline 15 & 50 & Saline & OK-432 & $580 \pm 218$ & (1) \\
\hline 15 & 50 & Fr. VI & OK-432 & $1324 \pm 604$ & (2.3) \\
\hline 15 & 50 & Fr. VII & OK-432 & $836 \pm 364$ & (1.4) \\
\hline
\end{tabular}

Mice at indicated ages were intravenously administered saline (control), $10 \mathrm{mg}$ Fr. VI or $20 \mathrm{mg} / \mathrm{kg} \mathrm{Fr}$. VII, and after $3 \mathrm{hr} 8 \mathrm{mg} / \mathrm{kg}$ OK-432. Two hr thereafter, sera were obtained and CF activity determined. Stimulation index was determined as in Table 3 . Each value is mean \pm S.E. of 3 mice.

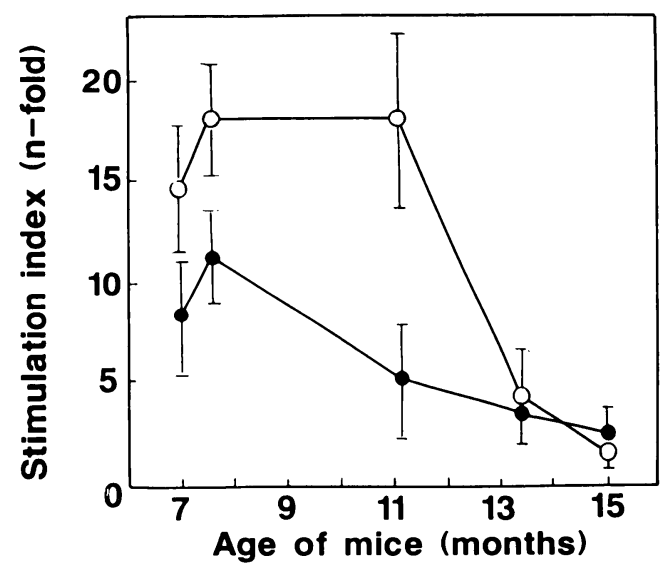

Fig. 2. Reduced endogenous CF production by aged mice.

Mice at indicated ages ( 3 mice/group) were administered saline (control), $10 \mathrm{mg} / \mathrm{kg}$ Fr. VI (๑) or $20 \mathrm{mg} / \mathrm{kg}$ Fr. VII (O), and after $3 \mathrm{more} \mathrm{hr,} 8 \mathrm{mg} / \mathrm{kg} \mathrm{OK}-432$. Two hr thereafter, the serum was obtained, and stimulation index determined as in Table 3.

\section{Effect of tumor implantation on endogenous $C F$ production.}

We next investigated the endogenous $\mathrm{CF}$ production by tumor-bearing mice. Mice intraperitoneally transplanted with $10^{6}$ sarcoma-180 cells all died within 21 days. Their mean survival time was 16.8 days. ${ }^{1)}$ During the late stage of tumor development, the stimulation effect of Fr. VI or Fr. VII on OK-432-induced CF production (judged by the stimulation index) declined significantly from $9.2-12.7$ on day 8 to $0.9-1.1$ on day 13 (Table 3, Exp. I).

Mice subcutaneously transplanted with sarcoma-180 cells also responded less to Fr. VI. No stimulation effect of Fr. VI was observed 13 days after solid tumor transplantation (Table 3, Exp. II).

\section{Effect of aging on endogenous $C F$ production}

We next investigated endogenous CF production by aged mice. Table 4 shows that treatment with Fr. VI or VII stimulated OK-432-induced CF production 11.3-17.9 times in younger mice ( 7 weeks old, $27 \mathrm{~g}$ ). The same treatments stimulated production only 1.4-2.3 
times in the older mice ( 15 weeks, $50 \mathrm{~g}$ ). Fig. 2 shows that the stimulation effect of Fr. VI or VII rapidly declined after the age of 11 weeks.

\section{Discussion}

This study revealed that intravenous administration of the pine cone antitumor substances, Fr. VI and VII, could endogenously produce proteineous CFs in mouse serum, upon subsequent treatment with OK-432. A previous report described the OK-432-induced factor(s) as TNF.9) It has recently been reported that a cytolytic factor secreted from BCG-activated macrophages is serologically related to necrosin, ${ }^{13)}$ the amino acid composition of which is analogous to that of TNF. ${ }^{14)}$ These data suggest that the CF identified in the present paper might be identical to TNF. As expected from the identity of TNF with differentiationinducing factor, ${ }^{15)}$ the serum obtained from mice stimulated with Fr. VI (or Fr. VII) and OK-432 induced monocytic differentiation in human myelogenous leukemic ML-1 cells (data not shown).

When the mice, which were inoculated with sarcoma-180 cells 2 weeks before, were sequentially treated with Fr. VI (or Fr. VII) and OK-432, growth of the transplanted tumor was significantly suppressed, and there was occasional necrosis (data not shown). This suggests the possibility that the induction of antitumor activity with either Fr. VI or Fr. VII might be mediated by CF production. However, the response of the mice to Fr. VI or Fr. VII was significantly reduced after they were implanted with tumor cells (Table 3). This supports a previous report that the capacity for TNF production broadly paralleled the survival rate in mice that received transplants of Ehrlich tumors. ${ }^{16)}$ We also found that the response of the mice to pine cone extracts declined when they aged (Table 4, Fig. 2). It is necessary to further investigate whether the reduced response of the tumor-bearing or aged mice might be due to the action of immunosuppressive substances. ${ }^{17}$ )

\section{Acknowledgments}

We thank Drs. K. Takeda, Y. Makino, M. Takeda, M. Tomita for valuable suggestions, and Dr. A. Simpson for help with the manuscript. This study was supported in part by Grant-in-Aid from the Ministry of Education, Science and Culture of Japan, and by the SHORAI Foundation for Science and Technology.

\section{References}

1) Sakagami H, Ikeda M, Unten S, Takeda K, Murayama J, Hamada A, Kimura K, Komatsu N and Konno K: Antitumor activity of polysaccharide fractions from pine cone extract of Pinus parviflora Sieb. et Zucc. Anticancer Res, 7: 1153-1160 (1987)

2) Unten S, Sakagami $\mathbf{H}$ and Konno K: Stimulation of granulocytic cell iodination by pine cone antitumor substances. J Leukocyte Biol, 45: 168-175 (1989)

3) Kurakata Y, Sakagami H, Takeda M, Konno K, Kitajima K, Ichikawa S, Hata N and Sato T: Mitogenic activity of pine cone extracts against cultured splenocytes from normal and tumor-bearing animals. Anticancer Res, 9: 961-966 (1989)

4) Harada H, Sakagami H, Konno K, Sato T, Ohsawa N, Fujimaki M and Komatsu N: Induction of antimicrobial activity by antitumor substances from pine cone extract of Pinus parviflora Sieb. et Zucc. Anticancer Res, 8: 581-588 (1988)

5) Abe M, Okamoto $\mathrm{K}$, Konno $\mathrm{K}$ and Sakagami $\mathrm{H}$ : Induction of antiparasite activity by pine cone lignin-related substances. In Vivo, 4: in press (1990)

6) Fukuchi K, Sakagami H, Ikeda M, Kawazoe Y, Oh-hara T, Konno K, Ichikawa S, Hata N, Kondo $\mathrm{H}$ and Nonoyama $\mathbf{M}$ : Inhibition of herpes simplex virus infection by pine cone antitumor substances. Anticancer Res, 9: 313-318 (1989) 
7) Fukuchi K, Sakagami H, Okuda T, Hatano T, Tanuma S, Kitajima K, Inoue, Y, Inoue S, Ishikawa $\mathrm{S}$, Nonoyama $\mathrm{M}$ and Konno $\mathrm{K}$ : Inhibition of herpes simplex virus infection by tannins and related compounds. Antiviral Res, 11: 285-298 (1989)

8) Sakagami H, Oh-hara T, Kaiya T, Kawazoe Y, Nonoyama M and Konno K: Molecular species of the antitumor and antiviral fraction from pine cone extract. Anticancer Res, 9: in press (1989)

9) Satoh M, Inagawa H, Shimada Y, Soma G, Oshima H and Mizuno D: Endogenous production of tumor necrosis factor in normal mice and human cancer patients by interferons and other cytokines combined with biological response modifiers of bacterial origin. J Biol Response Mod, 6: 512-524 (1987)

10) Okamoto H, Minami M, Shoin S, Koshimura $S$ and Shimizu R: Experimental anticancer studies. Part XXXI. On the streptococcal preparation having potent anticancer activity. Jpn J Exp Med, 36: $175-186$ (1966)

11) Sakagami H, Takeda K, Makino $Y$ and Konno K: Partial purification of novel differentiation-inducing substance(s) from hot water extract of Japanese pine cone. Jpn J Cancer Res, 77: 59-64 (1986)

12) Ruff MR and Gifford GE: Rabbit tumor necrosis factor: mechanism of action. Infect Immun, 31: 380-385 (1981)

13) Klostergaard J, Foster WA and Leroux ME: Tumoricidal effector mechanisms of murine BCGactivated macrophages. I. Parameters of production and initial characterization of a cytolytic factor serologically related to necrosin. J Biol Response Mod, 6: 313-330 (1987)

14) Ito A, Ohsawa $\mathrm{F}$ and Natori S: Purification of a cytotoxic protein produced by the murine macrophage-like cell line J774.1 in response to sarcophaga lectine. J Biochem, 99: 9-15 (1986)

15) Takeda K, Iwamoto S, Sugimoto H, Takuma T, Kawatani N, Noda M, Masaki A, Morise H, Arimura $\mathbf{H}$ and Konno K: Identity of differentiation inducing factor and tumor necrosis factor. Nature, 323: 338-340 (1986)

16) Haranaka K, Satomi N, Sakurai A, Haranaka R, Okada N and Kobayashi M: Antitumor activities and tumor necrosis factor producibility of traditional Chinese medicines and crude drugs. Cancer Immunol Immunother, 20: 1-5 (1985)

17) Fujii M, Fujii T, Saito K, Takahashi N, Yoshikumi C, Kakuchi J and Kawai Y: Tumor growth promoting activity of an immunosuppressive substance and its modulation by protein-bound polysaccharide PSK. Immunol Lett, 15: 347-351 (1987)

[Received August 31, 1989: Accepted October 11, 1989] 